\title{
Terracotta Temples of Bengal: A Culmination of Pre-existing Architectural Styles
}

\author{
Sudeshna Guha ${ }^{1} \&$ Dr. Abir Bandyopadhyay ${ }^{2}$ \\ ${ }^{1}$ B. Arch Student, National Institute of Technology Raipur, Raipur, Chhattisgarh, India. \\ Email: sudeshnaguha94@gmail.com \\ ${ }^{2}$ Professor, Department of Architecture, National Institute of Technology Raipur, Raipur, \\ Chhattisgarh, India. Email: abandyopadhyay.arch@nitrr.ac.in
}

\begin{abstract}
Three major developments in religious architecture were seen in three different eras of Bengal's history evolution of Nagara style temples which were influenced by the Orissan Rekha deuls, followed by the developments of Islamic Architecture through mosques and tombs, and lastly, the generation of Terracotta Temples. The Terracotta Temples of Bengal, famous for the use of Terracotta Plaques for surface decoration, had developed a unique style of architecture, quite distinct from the major styles of temple architecture that was prevailing in India. This paper intends to find out which architectural features of the Terracotta Temples got influenced and how they got influenced from the prevailing architectural styles.
\end{abstract}

Keywords: Terracotta Temples, influence, architectural features, Islamic architecture, Pre-Islamic architecture.

\section{INTRODUCTION}

\subsection{RELIGIOUS ARCHITECTURE OF BENGAL}

The region of Bengal consisting of present day West Bengal, Bangladesh, and some Bengali speaking areas of Bihar, Jharkhand, Assam, and Tripura (R.C. Majumdar, 1971) had witnessed development of a drastic divergent style of temple architecture. The initial phases (till 1200 A.D.) showed the development of typical Nagara style temples, while in the 'Late medieval period' (McCutchion, 2004) the temples started developing unique and distinct architectural characteristics. As per David McCutchion (2004), the development of religious architecture of Bengal is divided into three phases:

- Development of Ancient Temples (till $12^{\text {th }}$ century A.D., later in the Western areas)

- Development of Islamic Architecture (14 ${ }^{\text {th }}$ to early $16^{\text {th }}$ century A.D.)

- Rise of the Terracotta Temples $\left(16^{\text {th }}-19^{\text {th }}\right.$ century A.D.)

\subsection{ANCIENT TEMPLES:}

The remains of ancient temples belonging to the Pala Era (750 -1199 A.D.) and its later dynasties are generally Buddhist, Jain or converted Hindu temples (S. Haldar \& M. Haldar, 2011). Some of the notable examples are - Shiddheswar Temple of Bahulara, Bankura (80o-110oA.D.), Pakhbirra Temple, Purulia (10oo1100 A.D.), Satdeulia Temple of Memari, Bardhaman (1000-1100 A.D.)(www.aishee.org). The super-structure of these temples showcases the Nagara style of Indian temples; the Latina of which was derived from the

(c) AesthetixMS 2016. This Open Access article is published under a Creative Commons Attribution Non-Commercial 4.0 International License (http://creativecommons.org/licenses/by-nc/4.o/), which permits non-commercial re-use, distribution, and reproduction in any medium, provided the original work is properly cited. For citation use the DOI. For commercial re-use, please contact editor@chitrolekha.com 
phamsana - vallabhi - bhumija pattern of the aforementioned architectural style (Adam Hardy, 2007). Some of the temples, like Shiddheswar Temple of Bahulara had the provision for "mukhamandapa" or porch in front of main shrine but this practice diminished eventually (Brown, 1942).

\subsection{ISLAMIC ARCHITECTURE:}

After the invasion and victory of Muhammad Bakhtiyar Khilji at Nadia in 1204 A.D, (Dani, 1961) the Muslim rule begun, to be concentrated over the central and the eastern regions of Bengal. Hence, existing Islamic buildings such as mosques, mausoleums, forts, gateways, hammam-khanas, igdahs, (Mitchell, 1984), which were constructed during this period are found in these regions.

In reference to the different types of ground plans of mosques and tombs found in Bengal, it can be divided into two major types (Mitchell, 1984):

- The Courtyard type (example, Adina mosque)

- The Enclosed type

The enclosed type can be further subdivided into the Square Enclosed type and the Rectangular Enclosed type. Eklakhi tomb and Qadam Rasul mosque are examples of such types, respectively. Bricks and basalt stones are used as the major building materials. One of the outstanding features of Islamic Architecture of Bengal is the curved roof structure of the mosque and tombs (Grover, 2002).

\subsection{TERRACOTTA HINDU TEMPLES:}

A radically new category of temple structure which originated during the $16^{\text {th }}$ century and lasted till the $19^{\text {th }}$ century, A.D. (McCutchion, 2004), used burnt bricks as the chief building material. Terracotta panels were used to decorate the temple surfaces. The rise of these Terracotta Temples was influenced by the Vaishnava Movement particularly focusing on Radha-Krishna cult (McCutchion, ed. Mitchell, 1984). Religious tolerance among the Muslim Rulers; especially during the rule of Husain Shah (1493 - 1533 A.D.) coincided with the active life of Sri Chaitanyadev (1486 - 1533 A.D.) which in turn aided in the propagation of Vaishnavism (McCutchion, ed. Mitchell, 1984). Singhabahini temple at Ghatal, West Medinipur; Narasimha temple at Gokarna, Murshidabad and Krishna Balarama temple of Baghnapara, Bardhaman are some of the earliest known terracotta temples of West Bengal. But at present most of them have lost their original features as they have undergone major renovation (S. Basu \& A. Basu, 2015). However, the major evolution and variation in temples began under the patronage of the Malla rulers of Bishnupur (S. Basu \& A. Basu, 2015) and from there the styles got dispersed to different parts of West Bengal. The variation in the temple architecture came about due to their external appearance and not because of their structure (McCutchion, 2004). Use of different roof structures in each temple determined the external form of these temples (Sanyal, 2012).

The basic forms of temples that developed till $17^{\text {th }}$ century A.D. are generally classified as (Fig-1):

- Modified Rekha Deuls - with tower rising vertically up and gets curved at the end.

- Chala Temples - with sloping roofs which is further divided into:

- Do-chala - having two sloping roofs with a central ridge.

- Jor-Bangla - twin 'Do-chala' attached to each other.

- Char-chala - having four sloping roofs

- Aat-chala - having a smaller 'char-chala' added over a bigger 'char-chala'. 
- Ratna Temples - having a miniature tower above the main shrine. This can be 'Ek-Ratna' - for one tower, 'Pancha-Ratna' for five such towers which went up to 'Pancha-Vimsati' Ratna for twenty-five towers.

Apart from the above mentioned types, 'Rasmancha', 'Dolmancha', 'Dalan' or Flat-roofed temples, temples with multiple 'ratnas' or pinnacles above main shrine, Grouped temples, octagonal temples, etc. were also developed within succeeding years after the establishment of basic temple forms. However, such forms and structures of Terracotta temples are not considered within the scope of this research work.
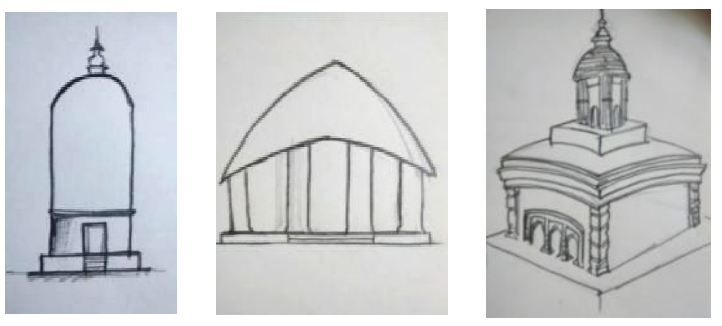

Figure 1: Schematic diagram of Modified Rekha Deul (left), Chala Temple (middle) \& Ratna Temple (right).

\section{PARAMETERS}

Ten architectural features of the Terracotta Temples that are considered as parameters to carry out the comparison between the sample buildings of different eras are as follows (Fig-2):

- plinth

- threshold

- columns

- entrance

- walls

- motifs

- corners

- roofs

- superstructure

- plan

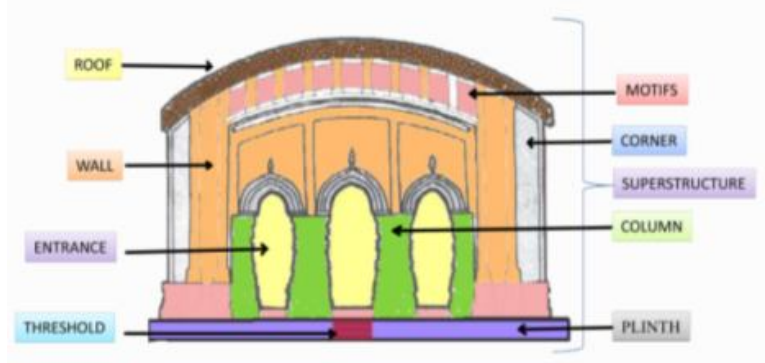

Figure 2: Parameters chosen for comparison

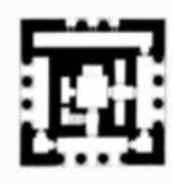

PLAN

\section{CRITERIA FOR SAMPLE SELECTION}

To carry out this comparative study, the Post-Islamic Terracotta Hindu temples, Islamic buildings, and the Pre-Islamic temples have been chosen on the basis of following criteria:

- Existing Temples, Mosques and Tombs with available data.

- Accessibility to the location.

- Proximity of the Post-Islamic Terracotta temples to the existing Pre-Islamic temples and Islamic Architectural buildings of that era.

- Basic forms of temples that developed within $16^{\text {th }}-17^{\text {th }}$ century A.D.

- Earliest construction Date of a particular type of temple. 
THE SAMPLES CHOSEN FOR CASE STUDY ARE:

Table 1: List of Pre-Islamic Temples, Islamic Religious Buildings, and Terracotta Temples (from top)

\begin{tabular}{|l|l|l|}
\hline NAME & DATE & PLACE \\
\hline SHIDDHESWAR TEMPLE & 800 A.D. & BAHULARA,ONDA,BANKURA \\
\hline BEGUNIA TEMPLE & 900 A.D. & BARAKAR, ASANSOL \\
\hline SATDEULIA TEMPLE & 1000 A.D. & SATDEULIA, MEMARI, BARDHAMAN \\
\hline BANDA TEMPLE & 1100 A.D. & BANDA, RAGHUNATHPUR, PURULIA \\
\hline NAME & DATE & PLACE \\
\hline ZAFAR KHAN GHAZI MOSQUE & 1298 A.D. & TRIBENI, HOOGHLY \\
\hline BARI MOSQUE & 1300 A.D. & CHOTA PANDUA, HOOGHLY \\
\hline ADINA MOSQUE & 1374 A.D. & PANDUA, MALDA \\
\hline EKLAKHI TOMB & 1412 A.D. & PANDUA, MALDA \\
\hline CHIKA MOSQUE & 1450 A.D. & GAUR, MALDA \\
\hline LATTAN MOSQUE & 1475 A.D. & GAUR, MALDA \\
\hline CHAMKATI MOSQUE & 1475 A.D. & GAUR, MALDA \\
\hline QADAM RASUL MOSQUE & 1530 A.D. & GAUR, MALDA \\
\hline NAME & DATE & PLACE \\
\hline RAGHUNATHJU TEMPLE & 1633 A.D. & GHURISHA, ILAMBAZAR, BIRBHUM \\
\hline SHYAM RAI TEMPLE & 1643 A.D. & BISHNUPUR, BANKURA \\
\hline KESHTA RAYA TEMPLE (JORBANGLA) & 1655 A.D. & BISHNUPUR, BANKURA \\
\hline RADHA VINOD TEMPLE & 1659 A.D. & BISHNUPUR, BANKURA \\
\hline MURALI MOHAN TEMPLE & 1665 A.D. & BISHNUPUR, BANKURA \\
\hline MADAN MOHAN TEMPLE & 1694 A.D. & BISHNUPUR, BANKURA \\
\hline
\end{tabular}
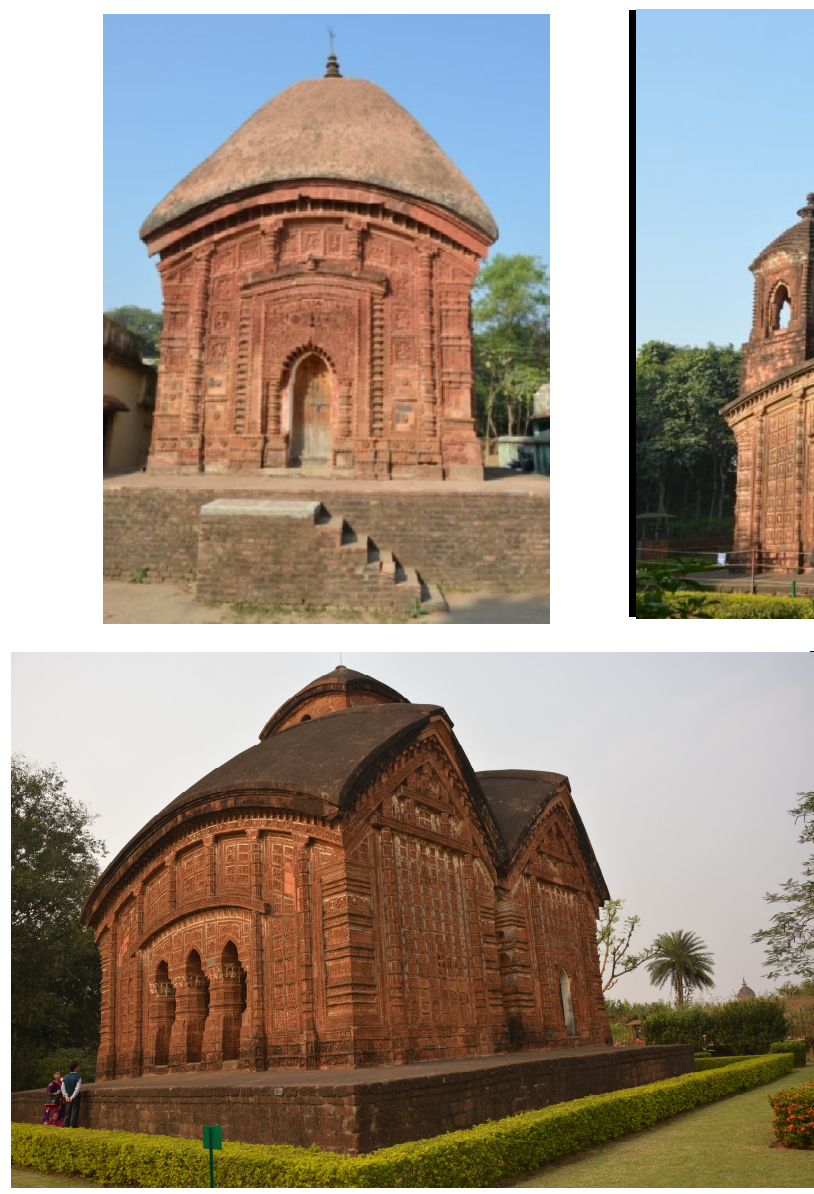
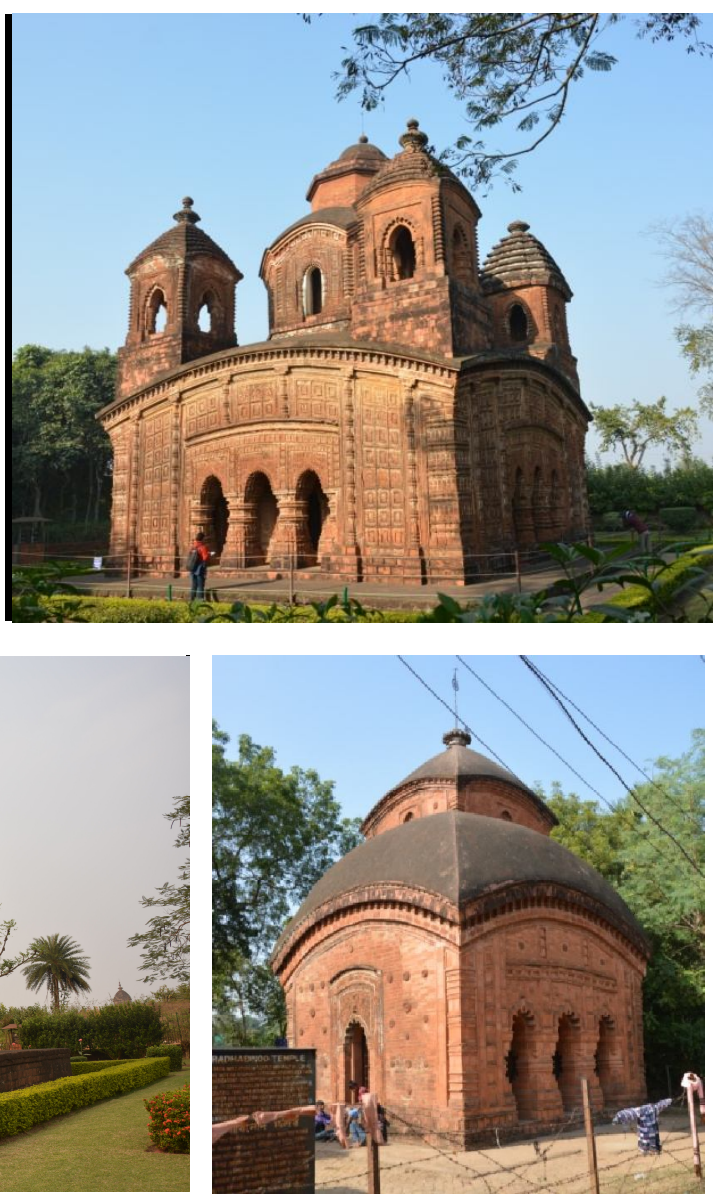

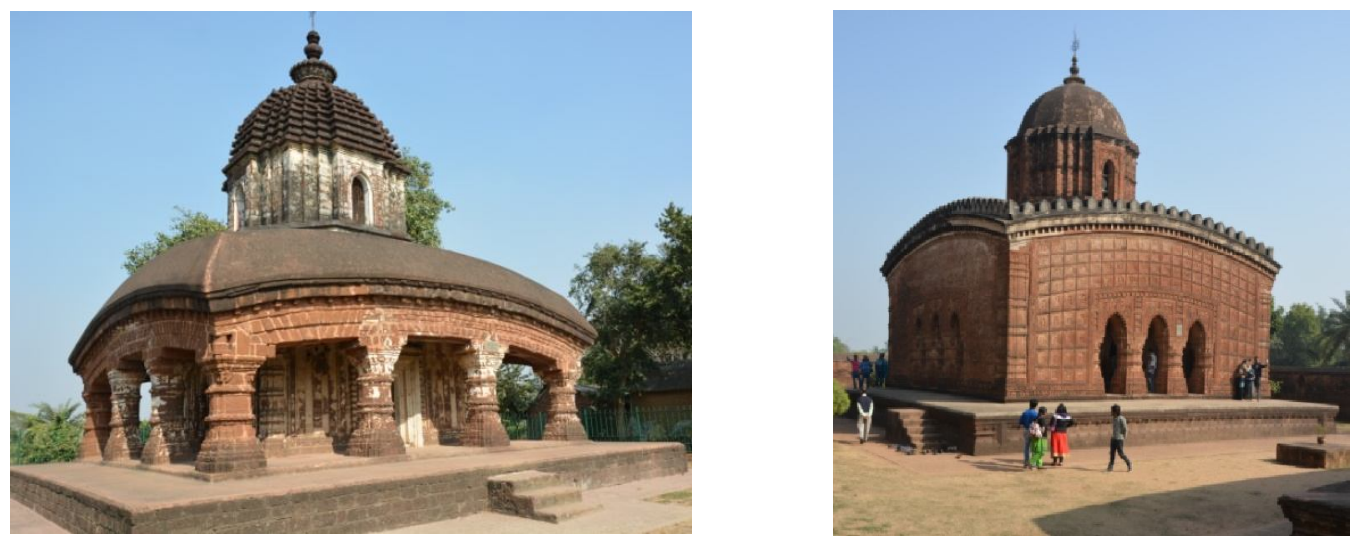

Figure 3: Terracotta Temples (from top): Raghunathiu Temple, Shyamrai Temple, Jor Bangla Temple, Radha Vinod Temple, Murali Mohan Temple, Madan Mohan Temple.

\section{ANALYSIS}

\subsection{PLINTHS:}

An average plinth height of $0.79 \mathrm{~m}$ is obtained from the above-mentioned Terracotta Temples considered for the case-study. The reason behind the high plinth height of these temples may be justified by the presence of pond or a bandh near to its site. It has been observed that the temples located near to a pond shows higher plinth than those which do not have a pond

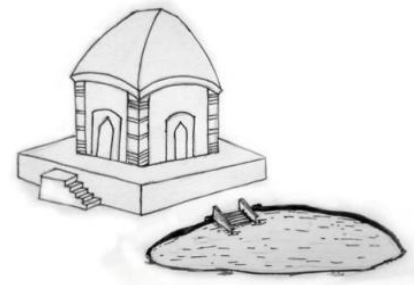

Figure 4: Temples near water body have higher plinth. near to it. Hence high plinths were provided to the temples to protect the sanctum from flooding.

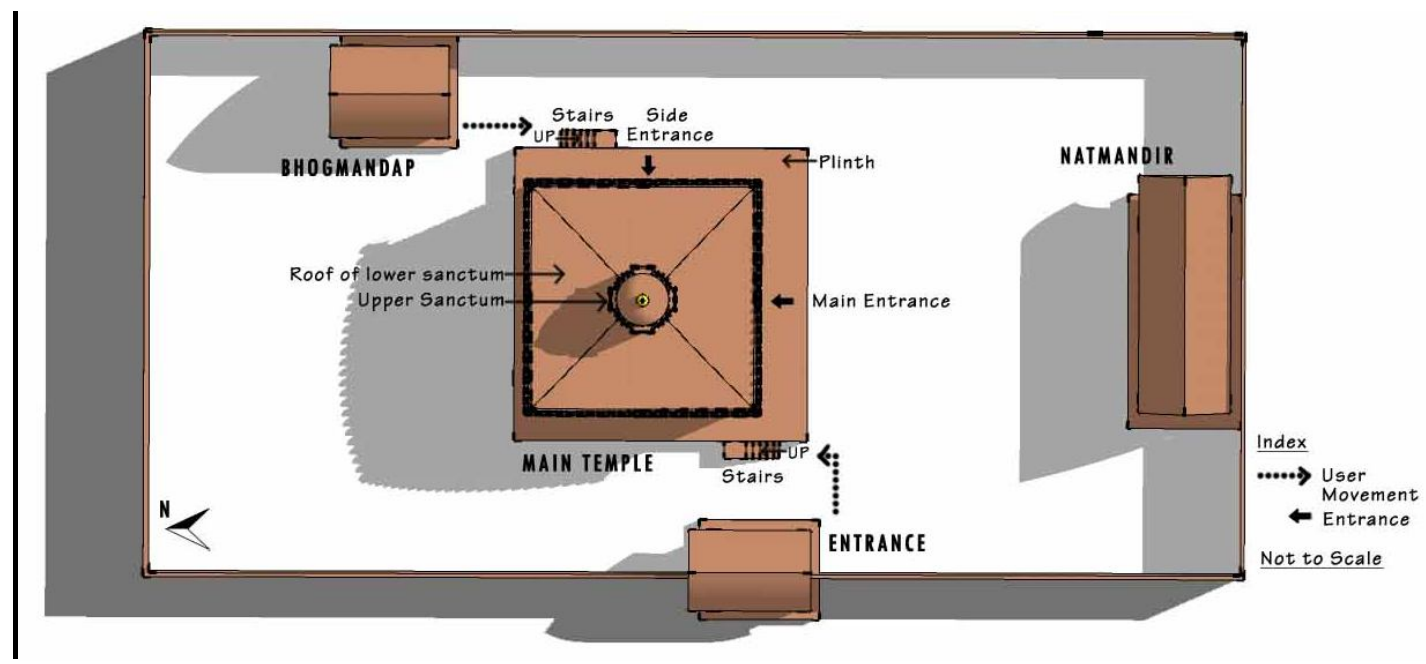

Figure 5: Schematic top-view of Madan Mohan Temple complex showing how Thresholds are positioned and directed according to the functional needs of the user.

\subsection{THRESHOLD:}

In most of the above cases where there is high plinth, the thresholds are positioned in front the Garbhagriha (sanctum sanctorum) to provide direct and easy access to the inner chamber, while in Madan 
Mohan Temple, two separate thresholds are present on either side of the main facade - one near the Bhogmandapa (hall of offering) and another in the opposite direction near the entrance. Ghosh (2005) describes, separate entranceways were provided to the sanctum - one being the main entrance and the other was used as 'service conduit'. The stairways are thus placed at such a position so that the priest had to cover minimum distance to enter the Garbhagriha from the main entrance of the temple complex, as well as from the Bhogmandapa (Fig-5). Hence the functional needs of the user directed the position and direction of threshold.

\subsection{COLUMN:}

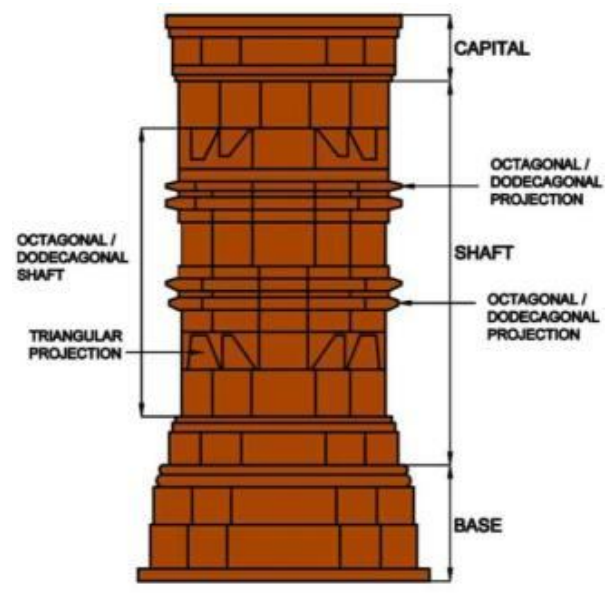

Figure 6: General diagram of the brick columns of the Terracotta Temples

panels used for ornamentation

Certain broken columns of PreChika Mosque in Gaur, Bari posses the same design feature, are much slender and longer 7). It might be that the design was influenced by the columns later had influenced the design Terracotta Temples (Fig-8).

The short, stout brick columns of the Terracotta Temples consists of a square brick capital, followed by an octagonal or dodecagonal shaft, intervened by two octagonal or do-decagonal projection and supported by a square base at the bottom (Fig-6). Gradual increase and decrease in width is seen throughout its length to create the column profile. Such design pattern is similar to the stone columns found in the Islamic Buildings such as in Zafar Khan Ghazi Mosque in Hooghly, Adina Mosque in Pandua, Qadam Rasul Mosque in Gaur, etc. However, the shape and dimensions of each segment of the stone column is dissimilar to that of the brick Terracotta columns - due to the use of nonuniform brick sizes and variation in the sizes of the Terracotta
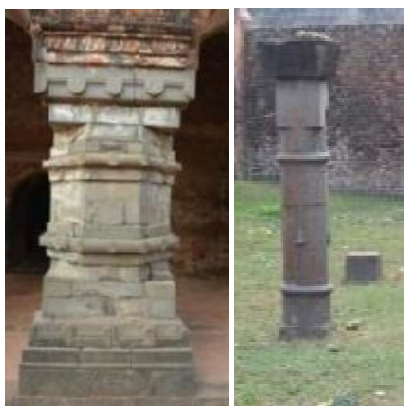

Figure 7: Column of Qadam Rasul Mosque (left) \& Pre-Islamic column at Bari Mosque (right).

Architects and builders of the contemporary period were not familiar with the loading distribution of domes, vaults and arches which were introduced with the Islamic rule in Bengal in $12^{\text {th }}$ century A.D. Hence, in order to support huge spans of dome, they used thick columns to carry the weight of the novel structural feature. However, since Pre-Islamic building parts were used in the construction of mosques and tombs, they adopted the design pattern of those building elements to keep in sync with such ornamentation. Later, such form of the columns became a trend in the construction procedure and was used as an architectural feature

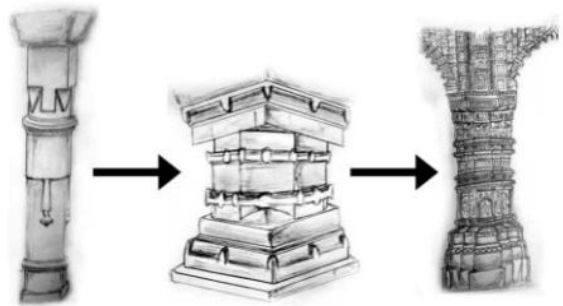

Figure 8: Probable process of evolution of columns - from Pre-Islamic columns to Islamic columns and then to Terracotta columns. irrespective of the fact that whether the building being constructed was a temple or a mosque. 


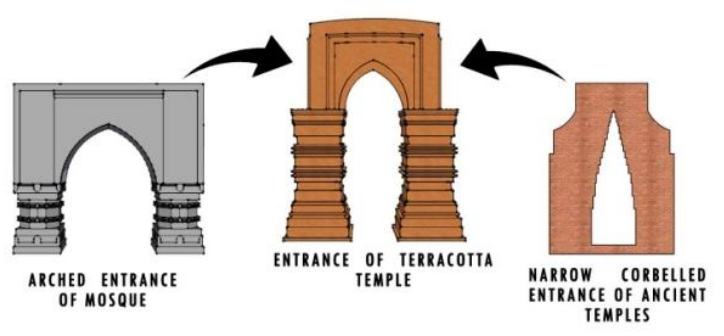

Figure 9: Architectural features of Mosque entrance (left) along with the concept of narrow entrance for ancient temples (right) led to the evolution of Terracotta temple entrance (middle).

\subsection{ENTRANCE}

Entrance to the porch: The triple archway entrance to the porch having Ogee arch or multi-cusped arches supported by the thick, short, stout columns on either side are similar to the main entrance of the mosques. Large clear span between the columns were provided in the mosques to allow easy mass movement towards the congregation chamber. In contrast to this, the Terracotta Temples have narrow arched entrance - may be to prohibit mass movement and to allow access only to the priest and royal family members. Space for mass congregation or performing kirtan was provided in the temple courtyard, but not within the main shrine. Even though the Terracotta temples were built to assist Vaishnava community congregation, it seems that the inner space and the entrance were

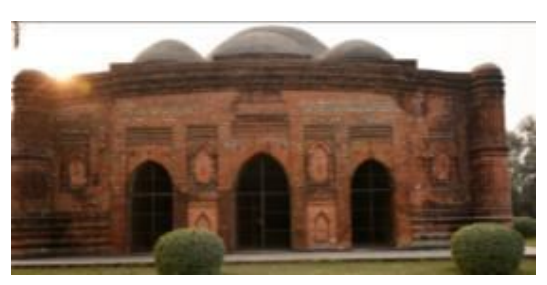

Figure 10: Triple archway entrance of Lattan Mosque deliberately made narrow to restrict any sort of mass performance or movement of the common people within the main shrine (Fig-9).

Rectangular Enclosed type mosques that developed after 1450 A.D. - The Lattan Mosque (Fig-10), Chamkati Mosque and Qadam Rasul Mosque, having three archway entrances in the front - served as the ideal model for the triple archway entrance of the Terracotta Temples.

\section{Entrance to the Garbhagriha}

The entrance to the Garbhagriha is marked by the presence of single multi-cusped arch supported by two engaged pilasters on either side. Each of the two pilasters consists of a vertical post like structure with horizontal projected moulding at intervals (Ghosh, 2005) (Fig-11). Such entrance frame is 'ornamented in manner of the Sultanate mosque's 'mihrab frame' (Ghosh, 2005). The concept of 'visual focus' through the mihrab frame - modified to form the door frame of the temple sanctum; has been explained by Pika Ghosh (2005).

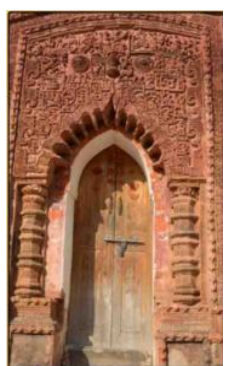

However, this prototype can be traced back to the PreIslamic Architecture, where there is the use of 'trefoil arch, springing from the side pillars' (Dani, 1961). It can be presumed that after the introduction of mihrab in mosques as a new element in architecture, especially in the initial stages, artisans used the broken niches of the Pre-Islamic buildings having trefoil arches for ornamenting the mihrabs. Later, with the experimentation for design variation, the trefoil arch was transfigured to multi-cusped arch, resting upon

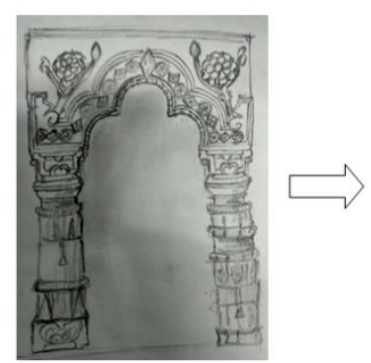

Figure 12: Probable process of evolution of entrance frames of Garbhagriha from the Pre-Islamic Trefoil arch (left) to Post-Islamic mihrab frame (right). short engaged pilasters (Fig-12). 


\subsection{WALLS AND FACADES:}

Wall thickness: A general comparison is done by considering the ratio of the wall thickness to the height of the sample buildings.

Table 2: Ratio of mean wall thickness to height of the Terracotta Temples and Islamic Buildings

\begin{tabular}{c|c|c|c|}
\hline TERRACOTTA TEMPLES & $\begin{array}{c}\text { WALL THICKNESS } \\
\text { (W)(mm) }\end{array}$ & HEIGHT(H)(mm) & W/H \\
\hline RAGHUNATHII (1633 A.D.) & 886.25 & 6539 & 0.135533 \\
\hline SHYAM RAI (1643 A.D.) & 1759.7 & 1142 & 0.157934 \\
\hline JOR BANGGA (1655 A.D.) & 792.11 & 11270 & 0.070285 \\
\hline RADHA VINOD (1659 A.D.) & 1112.4 & 8429.43 & 0.131966 \\
\hline MUROU MOHAN (1665 A.D.) & 757.55 & 8240 & 0.091936 \\
\hline MADAN MOHAN (1694 A.D.) & 1119.3 & 9330 & 0.119968 \\
\hline
\end{tabular}

MEAN W/H RATIO $=0.1179$

\begin{tabular}{c|c|c|c} 
ISLAMICBUILDINGS & $\begin{array}{c}\text { WALL THICKNESS } \\
(\mathbf{W})(\mathrm{mm})\end{array}$ & HEIGHT(H)(mm) & W/H \\
\hline ZAFAR KHANMOSQUE & 1700 & 8226 & 0.206662 \\
\hline EKLAKHITOMB & 3493 & 14650 & 0.23843 \\
\hline CHIKAMOSQUE & 4374.5 & 14448 & 0.302775 \\
\hline LATTANMOSQUE & 3219 & 11933 & 0.269756 \\
\hline QADAM RASULMOSQUE & 1443.5 & 12200 & 0.11832 \\
\hline
\end{tabular}

MEAN W/H RATIO $=0.2271$

Table 3: Ratio of Mean wall thickness to height of the Pre-Islamic Buildings

\begin{tabular}{c|c|c|c} 
PRE-ISLAMIC TEMPLES & $\begin{array}{c}\text { WALL THICKNESS } \\
(\mathrm{W})(\mathrm{mm})\end{array}$ & HEIGHT(H)(mm) & W/H \\
\hline BAHULARA & 2911 & 19507 & 0.149228 \\
\hline BEGUNIA & 1645 & 9657.5 & 0.170334 \\
\hline SATDEUL & 2225 & 17017.7 & 0.130746 \\
\hline PAKHBIRRA & 1680 & 8359 & 0.200981 \\
\hline BANDA & 1233.75 & 11847 & 0.10414 \\
\hline
\end{tabular}

$$
\text { MEAN W/H RATIO = } 0.1510
$$

This abrupt variation in the values obtained for mean wall thickness to height ratio might be the contribution of the difference in the building materials and the span of domes and vaults used in each type of buildings. When domes and vaults were first introduced as a major constructional feature in Islamic religious buildings, thick brick walls and columns were used to support the loads of the ceiling, as a supplementary to the use of stone. When this technique was followed in the construction of the temples, the wall thickness got reduced in comparison to the thick walls of the mosques and tombs. It may be inferred that the constructional technique had improved during the Post-Islamic Era which resulted in using walls of lesser thickness to carry similar loads.

\section{SHAPE \& ORNAMENTATION OF FACADE:}

Rectangular walls with upper curved cornice, richly ornamented with terracotta plaques and vertical longitudinal projections with horizontal mouldings at certain intervals - is the common front facade feature of the Terracotta Temples. Only the Murali Mohan Temple and facades of Jor Bangla

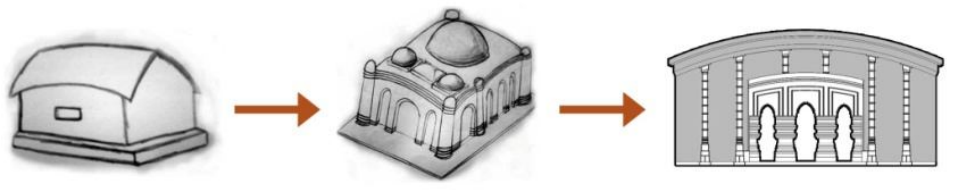

Figure 13: Probable process of evolution of facade having curved cornice Temple along east-west axis are the exceptions to this feature. Application of curved cornice to drain out rain water from the roofs quickly was seen in vernacular architecture and was later adopted in Islamic buildings that came up after 1400 A.D. and further got implemented on the cornices of the Terracotta Temples (Fig-13). 
The vertical projections seen on the facades of the Terracotta Temples are long, slender engaged pilasters with horizontal mouldings at regular intervals on the vertical post. These are similar to the repetition of internodes on a bamboo pole - used as supporting members in the huts. It can now be justified that the horizontal and vertical projections on the eastern and western walls of the Jor Bangla Temple are the replica of principle tie-beams, rafters and bamboo posts of Bengal huts (Fig-14). This feature can thus be regarded as replication of wooden construction technique on terracotta bricks.
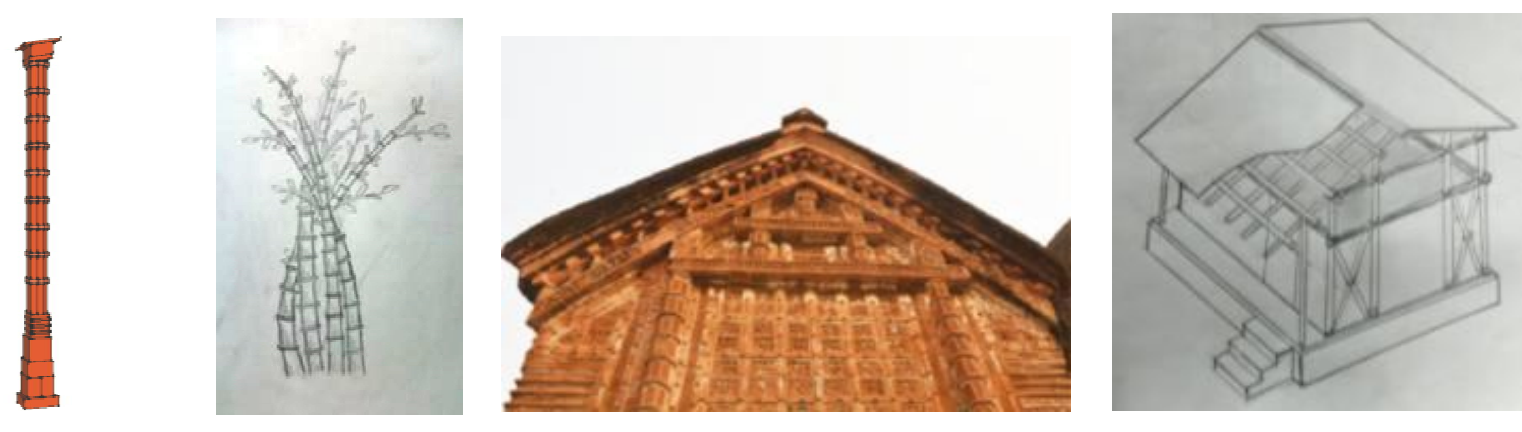

Figure 14: Vertical projection seen on the Temples (left) is similar to the bamboo pole (second from left). Vertical and horizontal projections on the facade of the Jor Bangla temple (second from the right) are replica of wooden posts and beams of vernacular architecture (right).

\subsection{MOTIFS:}

The Terracotta Temples of Bengal are famous for the terracotta motifs used for ornamentation on the temple walls 'as one of the most original and unique expressions of decorative temple art in the late medieval period of Bengal' (S.Haldar \& M. Haldar, 2011). Figurative sculptures of popular gods and goddesses, human in their dancing postures, conjugal postures, floral decorations, animal figures, etc. were generally used as themes for ornamentation. Along with these, activities of social lives, religious cult practices, scenes from the epics and wars were also depicted in the terracotta motifs. Other favourable themes depicted in the panels are certain floral designs similar to the arabesque designs of Islamic Architecture. Terracotta panels covering the corner elements of Madan Mohan Temple show arabesque designs similar to that found on the Eklakhi Tomb. The arabesque motif on the Tomb was carved out from the brick pieces; while the motifs seen on the Terracotta Temples were mostly casted out from wooden mould or are sometimes sculpted out in the form of plaques or tablets.

\section{LOTUS MOTIF}

Lotus motifs seen on the spandrels of entrance arch of the Garbhagriha at the Terracotta Temples is another important Islamic influence seen in the terracotta relief works. These are similar to the Lotus flower medallions used for decorating the spandrels of the mihrabs in a mosque (Fig-15).

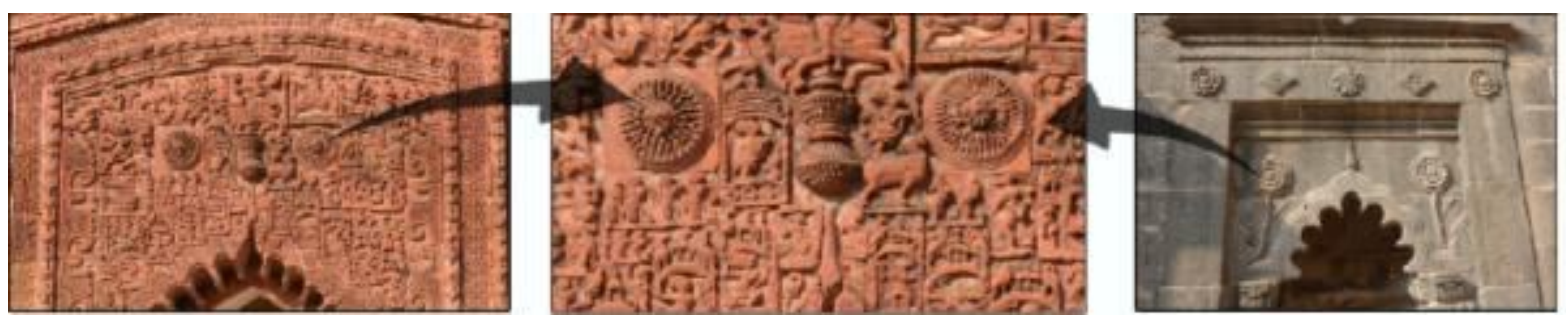

Figure 15: Lotus Medallion influenced from Mihrabs (right) can be seen on the Garbhagriha entrance frames (left $\mathcal{E}$ middle). 


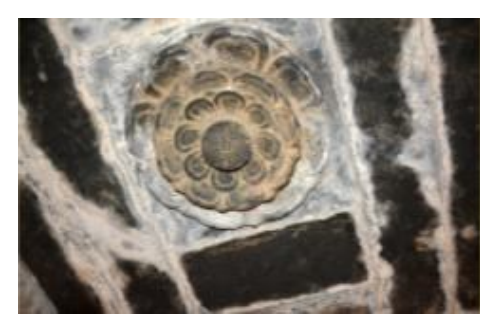

Figure 16: Lotus motif at the ceiling of takht in Adina mosque.

However, in some Pre-Islamic building parts for example in trabeated ceiling of temple used as ceiling in the takht at Adina Mosque shows a lotus stone motif at its centre (Fig-16\&17). This implies that the craftsmen were familiar with the inclusion of lotus motifs from the Pre-Islamic period. However after the initiation of Islamic Architecture, a new location was assigned to these motifs and it was then incorporated into the

Terracotta Temples. A further modification in the use of this motif was seen in the Madan Mohan Temple, where the lotus medallions got replaced by the rasmandals (Ghosh, 2005). Thus despite small differences, certain motifs like lotus medallions, floral patterns on door frames is repeated across the region, regardless of whether the building is dedicated to Islam or Gaudiya Vaishnavism.

Apart from this, segregation of the facade into separate panels using small linear terracotta 'bars' to allow separate terracotta plaques in each quadrangular spaces - was influenced by the facades of Bengal huts consisting of exposed bamboo frames or bamboo matting. Since most of the design features of the facades of Terracotta temples were derived from

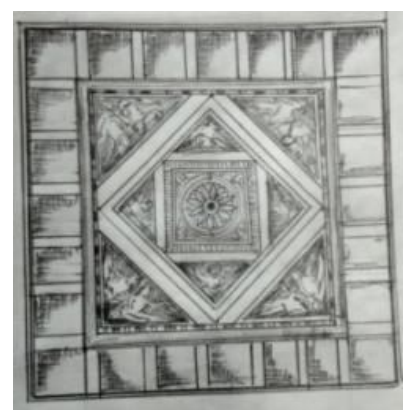

Figure 17: Lotus motif at the trabeated ceiling of Ancient temples vernacular architecture, it can be presumed that panelling feature is no exception to such fact.

\subsection{CORNERS:}

The corner elements in the Terracotta Temples show linear horizontal projections or mouldings at certain intervals. Though the gaps between the moulding varies, but the distribution of mouldings is similar in each of the surveyed temples. Such projections are analogous to the projected mouldings on the octagonal engaged turrets of mosques and tombs provided at the corners. This trend is found in every square or rectangular mosque and particularly in Qadam Rasul Mosque, the external corner of the inner chamber shows linear horizontal mouldings similar to that seen in the Terracotta Temples (Fig-18).

However, the design pattern seen in the mouldings of pabhaga and even the distribution of Barandi and Janghas on the Nagara Temple structures are similar to the mouldings used in ornamenting the engaged corners of the Mosques and Tombs. Thus the Islamic Corner turrets itself got influenced from the Pre-Islamic Temples which later had an impact on the corner elements of the Terracotta Temples (Fig-
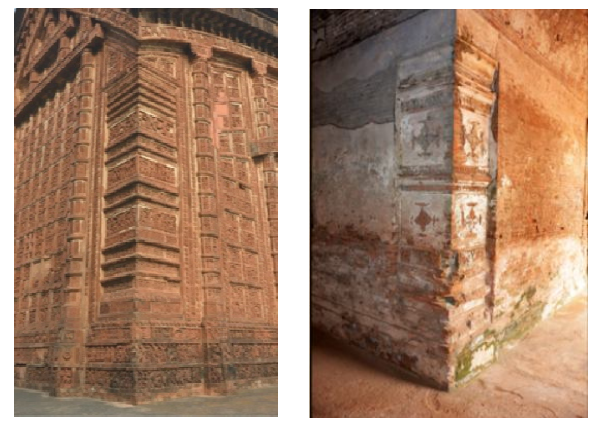

Figure 18: Corner elements at Jor Bangla Temple (left) and Qadam Rasul Mosque (right).

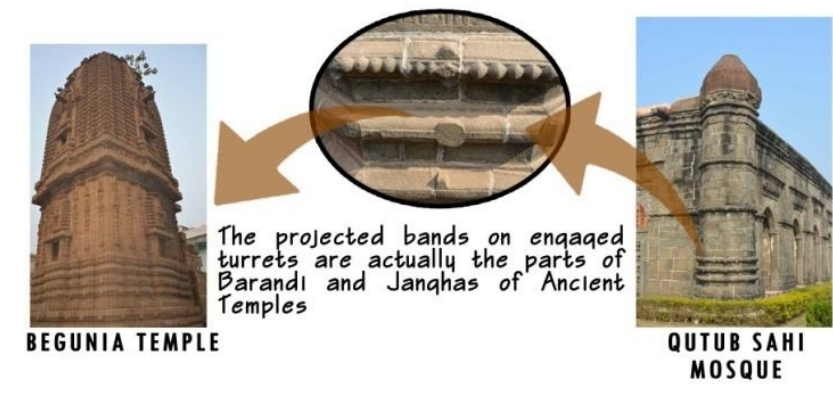

Figure 19: The Barandi and Jangha of Pre-Islamic Temples (left) influenced the engaged turrets of Islamic Architecture (right) which further influenced the corners of Terracotta Temples. 19). 


\subsection{ROOFS:}

The roofs play a crucial factor in determining the style of the Terracotta Temples. Roof patterns of these temples can be divided into two types:

- External Roof Pattern

- Internal Ceiling Pattern

\section{External Roof Pattern:}

Externally three types of roof pattern can be identified in these temples.

- Curved roof pattern - found in Madan Mohan, Shyam Rai and Murali Mohan Temples

- Do Chala Roof Pattern

- Char Chala Roof Pattern

These roof patterns were originally inspired by the vernacular architecture of Bengal, which provided easy drainage of rain water from the roofs of Bengal huts. Such patterns were replicated using brick as the chief building material in Islamic architecture, which later influenced the Terracotta Temples.

\section{Internal Ceiling Pattern:}

In contrast to the external roof pattern, the internal ceiling feature of the temples shows the use of Domes, pointed barrel vaults and chala vaults which were a result of influence from Islamic Architecture; whereas corbelled vault was inspired by Pre-Islamic Architecture (Fig-2o). Various styles of ceiling have been used to cover different spaces designated in the plan of a Terracotta Temple. Generally domes supported by pendentives or
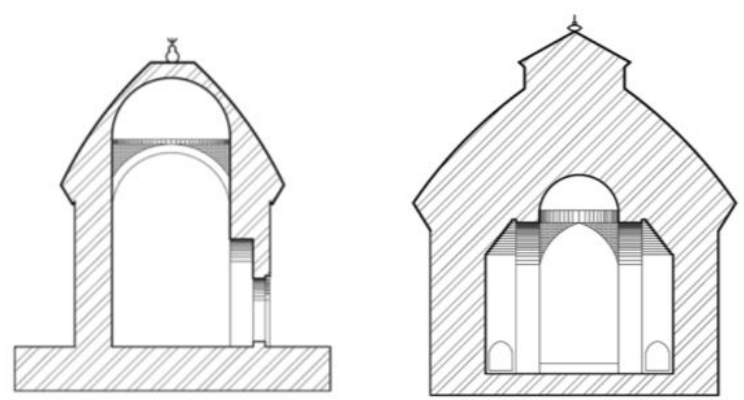

Figure 20: Section of Raghunathjiu Temple (left) and Radha Vinod Temple (right) showing dome and corbel construction. squinches are used to cover square shaped space, whereas pointed barrel vault or semi barrel vaults are used to cover rectangular spaces. This feature is quite common to the style used in Islamic Architecture especially among the styles found in the Rectangular Enclosed mosques.

\subsection{SUPERSTRUCTURE:}

The superstructure of the Terracotta Temples which have been surveyed for the study can be classified into two types based on the origin of external form:

- Chala Temples

- Ratna Temples

The form of the superstructure for the chala temples was derived from the typical Bengal huts with thatched sloping roofs. The roof form played the crucial factor for determining the form of the superstructure. Otherwise, without the roof, every temple would have looked similar.

The Ratna Temples represented newly evolved architectural forms among the Terracotta Temples whose significant characteristic is the addition of an upper pavilion above the main shrine. Pika Ghosh, (2005) has tried to explain the reasons behind the formation of the Ratna Temples based on the following factors: 
- Religious and Functional Purpose

- Symbol of Domination

- Symbolic Continuity of Sultanate Rule

- God as a member of Family

- Portability of Gods

These provoked the artisans to devise a new model for temple construction. The form of the lower sanctum was influenced by the exterior form of the mosques having curved cornice, whereas the form of the upper sanctum was a result of mixed influence from the curvilinear tower of the modified Orissan Rekha deuls and ridged roof structures of the pidha deuls of Bengal. The external facades of the upper sanctum show 'ratha' projections (triratha, pancharatha or saptaratha) on all sides - a prominent architectural feature of Nagara temples (Fig-21). But the concept of spaces - private room at upper level and semi-private room at lower level - was inspired by the distribution of spaces seen in Aat-chala vernacular houses of Bengal (Fig22).

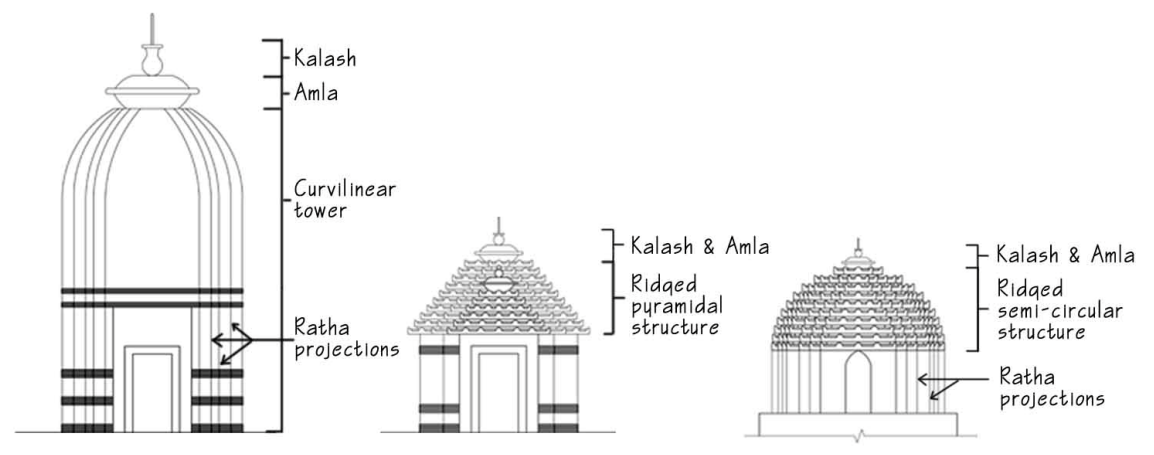

Figure 21: The form of the upper sanctum (right) has derived from the combination of curvilinear tower of modified Rekha deul (left) and ridged pyramidal covering of pidha deul (middle) with ratha projections on its facades.

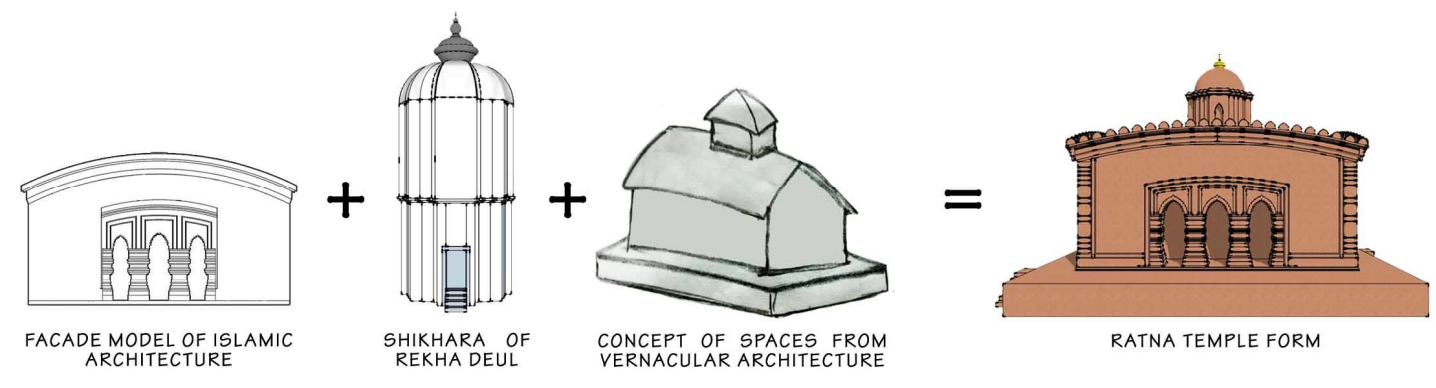

Figure 22: Probable process of evolution of Superstructure.

2.10 PLAN:

A general Terracotta Temple plan shows a square shaped Garbhagriha flanked by rectangular porches around it. A square shaped Garbhagriha had always been the basic plan for a Nagara temple. However, Rectangular enclosed mosques constructed after 1400 A.D. showed gradual development from a single inner chamber (example, Chika Mosque) to porches flanking the three sides of the square chamber (example, Qadam Rasul Mosque). Thus, the plans for the Terracotta Temples might have been derived from the combination of plans associated with the preceding architectural styles (Fig-23). Two separate entrances to the Garbhagriha are provided along two sides of the square sanctorum - the south opening being the main entrance and the east entrance is for the services, like bringing the bhog from the Bhogmandapa. Provision 
of spaces for Natmandir (entertainment hall), Bhogmandapa were assigned as per the functional requirements and religious beliefs of the Vaishnava community.

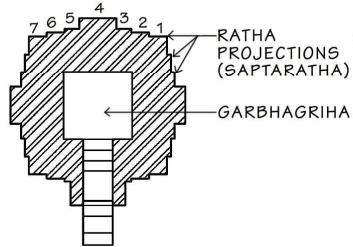

BARAKAR TEMPLE

PLAN

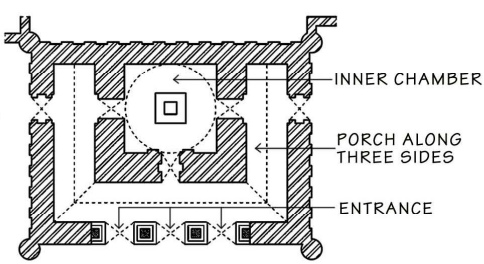

QADAM RASUL MOSQUE

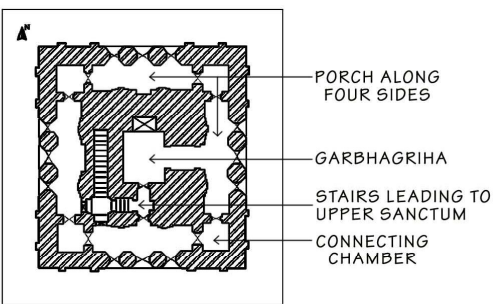

SHYAM RAI PLAN

Figure 23: Probable process of evolution - Combination of Spaces of a Nagara Temple (left) and a mosque (middle) led to the evolution of Terracotta Temple Plans (right).

\section{CONCLUSION}

The Terracotta Temples of Bengal stand as the epitome of culmination of various influencing factors - be it the geographical, geological, structural, social or political factors. The architectural features of the Islamic buildings of Bengal, made before these Terracotta Temples, were influenced by the then existing Hindu Temples (many of the early Islamic buildings show evidence of using broken parts of pre-existing temple structure as their building elements) and also by the existing vernacular architecture of Bengal. The construction of such buildings served two purposes -

- It created a unique "style", completely distinct from the prevailing Persian style of Islamic architecture - to be idealized and imitated in the future building to come, and,

- Created a specialized craftsmanship which trained the local people about this "style" - to be incorporated in the future Terracotta Temples.

Change in building construction materials (from stone to brick) lead to a change in the proportion, size, and construction techniques of the buildings - showing an evolution of applied technology and experimentation with new materials. The use of terracotta as building materials also influenced the "sculpting" and motifs of the temples. The new material demanded that now the sculptures are to be "moulded" and not carved (as in stone) but the influence of arabesque and arcuated designs from Islamic architecture cannot be ruled out. The ingenuity of the craftsman should be credited for creating such divergent form of temple architecture; however, their skills would have remained unexplored unless there was religious tolerance among the Muslim rulers like Husain Shah who assisted in propagation of Vaishnavism under the leadership of Sri Chaitanyadeb. Local rulers and zamindars who seized this opportunity to gain recognition in the Islam dominated society, patronized the cultivation of such temple forms. Similar series of events that took place in the history of Bengal provided us with a new vocabulary of architectural evolution - a culminated product of apt fusion of Pre-Islamic Hindu, vernacular and Islamic styles, along with incorporation of the social, cultural \& religious requirements of the contemporary population. Thus, these Terracotta Temples of Bengal stands uniquely supreme as far as then current architecture is concerned. 
59 | The Chitrolekha Journal on Art and Design, Vol. 1, No. 1, 2017

\section{REFERENCES:}

Majumdar, R.C. 1971. History of Ancient Bengal, G. Bharadwaj \& Co., Calcutta. Pg - 1, 2.

McCutchion, David. 2004. Late Mediaeval Temples of Bengal, Asiatic Society, Kolkata. Pg: 1-14, 56.

Haldar, M. \& S. Haldar. 2011. Temple architecture of Bengal, Urbee Prakashan, Kolkata, Pg: 35-74

http://www.aishee.org/temples/index.php

Hardy, Adam. 2007. The Temple Architecture of India. Great Britain: Wiley. Pg: 202

Brown, Percy. 1942. Indian Architecture: Buddhists and Hindu Period. Bombay: Taraporevala \& Sons. Pg: 149 $-150,1$.

Dani, A.H. 1961. Muslim Architecture of Bengal, Dacca, Pg: 1, 53, 54, 64 - 65.

Mitchell, George. 1984. The Islamic heritage of Bengal, United Nations Educational,Scientific and Cultural Organization, Pg: 21, 141

Grover, Satish. 2002. Buddhist and Hindu Architecture in India, CBS publishers and Distributors PVT. LTD. Pg: $76,54,56$.

Mitchell, George, Ed. 1984. Brick Temples of Bengal: From the archives of David McCutchion. Princeton University Press. Pg: 14

Basu, S. \& A. Basu. 2015. Banglar Terracotta Mandir - Akhyan O Alonkoron, Signet Press, Calcutta. Pg: 4

Sanyal, Hitesranjan. 2012, Banglar Mandir, Karigar publishers, Kolkata. Pg: 23, 37, 94

Mangaonkar, Priyanka. 2011. Terracotta Temples of Bishnupur: Transformation through Time and Technology, Chitrolekha International Magazine on Art and Design, Vol. 1, No. 2, Pg: 14, 19-20.

Ghosh, Pika. 2005. Temple to Love, Indiana University Press, USA, Pg: 10, 146 - 147, 2-9, 39, 78. 